\title{
Review of the Survey's activities in 1976
}

\author{
K. Ellitsgaard-Rasmussen .
}

Director

In 1976 the first petroleum exploration well was drilled on the shelf off West Greenland. This marked an important stage in the development of petroleum exploration in Greenland following the granting of concessions in April 1975 by the Ministry for Greenland. GGU's Oil and Gas Section was closely involved in the assessment of the drilling programme and in following the operation. Sample material and data were submitted during and after the drilling to the Ministry for Greenland and were studied in the Survey as part of the follow-up procedure. Several members of the GGU staff visited the drill ship Pelican during the summer.

On shore GGU has followed closely the progress of mining of zinc and lead at Mârmorilik by Greenex A/S which is now in its 4th year. In addition to control in the mine itself, detailed studies of the effects of the dumping of waste from the mine into the adjacent fjord have continued. As in previous years analyses of water, bottom deposits, sea weed, mussels and fish have been carried out in collaboration with Greenland Fishery Investigations and the Institute of Petrology, Copenhagen University. Detailed results of the survey up to summer 1975 were issued as the fourth number of Recipientundersøgelse.

In the area around Kvanefjeld in South Greenland a group has continued a study of the local environment before possible mining of the uranium from the Kvanefjeld deposit. This study includes the Quaternary geology of the Narssaq area, collection of climatological and hydrological data within the Narssaq Elv basin, weathering activity and soils, botany, limnology and marine biology. The 'Narssaq project' is a joint project supported by the Danish Natural Science Research Council (SNF) and involves personnel from the Institute of Petrology, Geological Museum, Botanical Museum and the Institute for General Zoology of the University of Copenhagen, and the Freshwater Biology Laboratory.

Uranium prospecting has continued in northern East Greenland with follow-up work after the airborne radiometric surveys of previous years. The work in $\mathbf{1 9 7 6}$ was concentrated on detailed investigations of the anomalies previously located, and a detailed geochemical water sampling programme in selected areas.

In West Greenland airborne radiometry and magnetic surveys continued using Søndre Strømfjord as the operation base. Work in 1976 was concentrated in the region to the north and south of Søndre Strømfjord and included activities as far north as Svartenhuk Halvø. This phase of the airborne geophysical work is now completed. 
Great interest has been shown in the potential of hydro-electric power in West Greenland. Local towns have put forward ideas for small projects and, in cooperation with Greenlands Technical Organisation (GTO) a study has been initiated of four basins near the Inland Ice in South and West Greenland.

Following the completion of mapping from the base at Midgard in the Fiskenæsset region emphasis has shifted from detailed systematic mapping of the west coast to regional mapping with a view to publication at 1:500000. It is hoped to cover the greater part of Greenland by geological maps at this scale in the foreseeable future, thus gaining a good working basis of the regional geology of the whole of Greenland before resuming systematic detailed mapping of selected areas. Field work for the 1:500000 geological map from Søndre Strømfjord to Frederikshåbs Isblink is expected to be completed in 1978.

With a major project for the regional mapping of North Greenland expected to commence in 1978, preliminary studies are in progress, and in 1976 a small group worked in the Cambrian-Silurian of Washington Land. The work involved the measuring of standard profiles and the checking on the ground of photointerpretation in the laboratory. The work was co-ordinated with parties from the Institute for Surveying and Photogrammetry, Denmarks Technical University (supported by the Danish Natural and Technical Science Research Councils (SNF \& STF)) and the Geodetic Institute.

In connection with the 1:500 000 regional mapping of south-eastern Greenland, a geological and geophysical party worked with the motor cutter Tycho Brahe in the Nagssugtoqidian mobile belt north of Angmagssalik.

A number of regional geological studies were co-ordinated with uranium prospecting activity in northern East Greenland. These included geochronological sampling in the crystalline complexes, studies of the Triassic sediments (one team supported by SNF) and the Tertiary basalts.

A team also completed the mapping of the southern tip of Svartenhuk Halvø in West Greenland in preparation for the compilation of the map sheet $71 \mathrm{~V} 1 \mathrm{~S}$ at 1:100000.

During 1976 GGU continued joint projects with the Danish Natural Science Research Council (SNF) namely, a micropalaeontological study of material from the Cretaceous-Tertiary of the Nûgssuaq embayment, West Greenland, and a sedimentological study of the Triassic in East Greenland.

A project was undertaken on Nûgssuaq to collect material by shallow coredrilling for a study of the organic content of the sediments and to evaluate the influence of weathering on surface samples. This project was run in conjunction with Programmgruppe für Erdöl und organische Geochemie in Jülich and wàs financed jointly by SNF and EOG. In addition, material was collected for a study of the thermal influence of igneous bodies on the organic material in the sediments. The joint programme with the University of Aarhus on the mapping of the 1:100000 


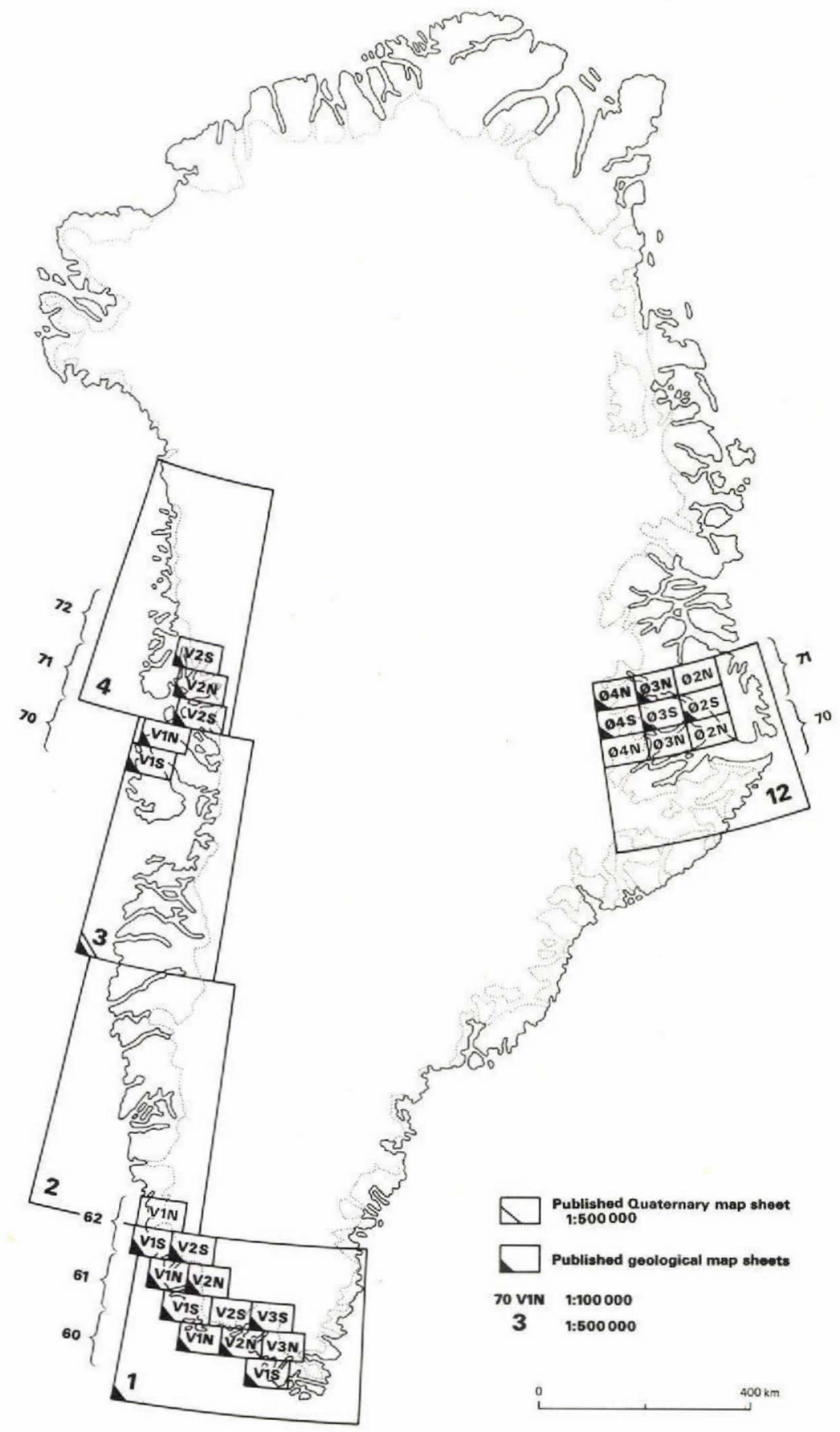

Fig. 3. Map sheets published and in preparation by the Survey (see inside rear cover). 
sheet Agto in the Nagssugtoqidian mobile belt in West Greenland continued during the year. A similar project in collaboration with the University of Exeter on the 1:100000 sheet Buksefjorden continued and is due to have its final field season in 1977.

A study of raised beaches and collections of shells for age dating was made in two areas; northern Greenland and western Disko. In North Greenland transport facilities were provided by the Royal Danish Air Force.

Five geological map sheets were published during the year:

\section{1:100000 West Greenland}

Nerutussoq $62 \mathrm{~V} 1 \mathrm{~S}$

Nigerdligassik $62 \mathrm{~V} 2 \mathrm{~S}$

Qutdligssat $70 \mathrm{~V} 1 \mathrm{~S}$
1:100000 East Greenland

Renland $71 \emptyset 3 \mathrm{~S}$

Gurreholm $71 \emptyset 2 \mathrm{~S}$

A total of 19 geological map sheets at 1:100 000 have now been published. Other published map sheets include two geological sheets at 1:500000 and one Quaternary sheet at 1:500000 (fig. 3) as well as a tectonic/geological and a Quaternary map sheet at 1:2500000 covering the whole of Greenland (see inside back cover for details).

During the year the book Geology of Greenland was issued. The publication of this comprehensive modern account of Greenland geology has long been awaited. International reception and reviews of the book have been very favourable. Other publications issued during the year include 3 Bulletins, 6 Reports and 15 Miscellaneous Papers.

There were three newcomers to the scientific staff during the year; a geologist and a palaeontologist being attached to the Mapping Department to take part in the North Greenland Project and a micropalaeontologist attached to the Oil and Gas Section to help with the extra work involved with supervision of the offshore drilling.

In Copenhagen most of GGU moved its location to a different wing of the same building giving better working space and facilities. This should be GGU's permanent home for the foreseeable future. 